\title{
Fish oil for human health: omega-3 fatty acid profiles of marine seafood species
}

\author{
Mustafa DURMUŞ
}

\begin{abstract}
The purpose of this study was to investigate the fat contents and fatty acid profiles of the edible meat of 13 different seafood species caught in the Northeastern Mediterranean coast. The fatty acid compositions of seafood species ranged from $27.68 \%$ to $36.59 \%$ saturated fatty acids, $8.99 \%$ to $35.84 \%$ monounsaturated fatty acids and $10.69 \%$ to $39.57 \%$ polyunsaturated fatty acids. Myristic acid (C14:0, 0.93-5.59\%), palmitic acid (C16:0, 13.68-23.89\%), palmitoleic acid (C16:1n7, 0.85-6.00\%), heptadecanoic acid (C17:0, 0.67-2.23\%), stearic acid (C18:0, 6.82-10.89\%), vaccenic acid (C18:1n-7, 1.05-4.01\%), oleic acid (C18:1n-9, 4.87-28.73\%), linoleic acid (C18:2n-6, 0.32-2.63\%), arachidonic acid (C20:4n-6, 0.22-0,82\%), eicosapentaenoic acid (C20:5n-3, 1.72-10.73\%) and docosahexaenoic acid (C22:6n-3, 4.07-31.44\%) were the most important fatty acids in most of species. All seafood species had high levels of EPA and DHA and much higher total n-3 PUFA than n-6 PUFA content. The ratio of w6/w3 PUFAs ranged from 0.02 in European squid to 0.48 in striped piggy. Atherogenicity (IA) and Thrombogenicity Index (IT) values ranged from 0.40 to 0.87 and from 0.17 to 0.79 , respectively.
\end{abstract}

Keywords: seafoods; fatty acids; pufa; atherogenicity index; Thrombogenicity Index.

Practical Application: Demonstrate the importance of commercial seafood in terms of human health and nutrition.

\section{Introduction}

Marine bioactive components from marine resources such as oils from fish, algae and the blubber of of marine mammals (seals and whales) and shark liver contain high level of w3-polyunsaturated fatty acids (PUFA) such as eicosapentaenoic acid (EPA, C20:5w3), docosapentaenoic acid (DPA, C22:5w3) and docosahexaenoic acid (DHA, C22:6 w3), chitin, chitosan, enzymes, peptides, vitamins (A, D and E), seaweeds, protein hydrolysates (Suleria et al., 2016; Rasmussen \& Morrissey, 2007; Lordan et al., 2011). Among marine bioactives, fish oils have received much attention in recent years. The importance of long chain $n-3$ fatty acids found in seafood is known worldwide and essential for the management of cardiovascular diseases. The consumption of polyunsaturated fatty acids, especially EPA and DHA from the omega- 3 fatty acid series can prevent the formation of many diseases in humans, especially cardiovascular disorders by reducing risk factors such as heart arrhythmias, blood pressure, triglyceride concentrations and platelet aggregation (Raatz \& Bibus, 2016; Fung et al., 2009; Mol, 2008). In addition, human diet enriched with fish oil was determined to have beneficial effects in the prevention of cognitive disorders (Graciano et al., 2016; Pinel et al., 2014) and brain development for children and aged people (He et al., 2017). High-dose fish oil (>6 g/day) and concentrated omega-3 fatty acids ( $4 \mathrm{~g} /$ day) are used as triglyceride lowering agents in patients with significant hypertriglyceridemia (Asztalos et al., 2016). While $1 \mathrm{~g}$ fish oil capsule containing up to $200 \mathrm{mg}$ of DHA and $300 \mathrm{mg}$ of EPA is recommended by the health service, two capsules are recommended daily for preventive therapy. DHA is a significant component of the brain, retina and sperm. Problems such as depression, memory loss, Alzheimer's, schizophrenia and visual disorders arise from the decrease of DHA level in brain cells (Kaya et al., 2004). Children who consumed fish at least twice a week, including one of the fatty fish, were found to be less likely to show emotional and behavioral problems than those did not (Gispert-Llaurado et al., 2016). Rendeiro et al. (2016) suggested that a diet rich in omega-3 PUFAs might help cure neurogenic deficits induced by chemotherapy. Omega-3 fatty acids protect against the development of certain cancers such as breast (Rendeiro et al., 2016; Palmquist, 2009; Stoll, 2002) and prostate cancer (Itsiopoulos et al., 2009). Fish oils are also known to have beneficial effects in diabetic patients (Pinel et al., 2014). Moreover, fatty acids have been reported to have positive effects in the treatment of patients with AIDS (Vieira \& Silveira, 2017; Tort et al., 2016). Given the high benefits of consuming seafood in human health, the American Heart Association Nutrition Committee suggests eating fish of 2 or 3 times a week (Kris-Etherton et al., 2003; Mnari et al., 2007).

Oils obtained from seafood are also used in food, pharmaceutical products, and as an ingredients in feeds, agricultural and aquaculture industries (Shepherd \& Jackson, 2013). Therefore, the determination of the amount of fat and fatty acids in seafood is essential. Many researchers have investigated the nutritional characteristic of seafood species in the Northeastern Mediterranean (Ozogul et al., 2009; Pethybridge et al., 2014; Cardona et al., 2015). Since the lipit content and fatty acid profiles of seafood are affected by many factors such as diet, salinity, temperature, age, season and sex (Ackman, 1989; Saito et al., 1999; Ozyurt \& Polat, 2006; Ozogul et al., 2009), updating of nutritional information of economically important seafood species is important for seafood industry and also consumer health. Therefore, in the current 
study an attempt has been made to determine the fat contents and fatty acid profiles of thirteen different seafood species caught in the Northeastern Mediterranean coast.

\section{Materials and methods}

\subsection{Sampling}

Thirteen fish species were caught in Northeastern Mediterranean between coordinates $36^{\circ} 43^{\prime} 31.8^{\prime \prime} \mathrm{N}, 34^{\circ} 54^{\prime} 27.0^{\prime \prime} \mathrm{E}$ and $36^{\circ} 08^{\prime} 53.6^{\prime \prime} \mathrm{N}$, $33^{\circ} 39^{\prime} 40.7^{\prime \prime} \mathrm{E}$ (Figure 1) using a commercial trawler in December 2016. The captured seafoods were 1 or 2 hours post-capture on arrival at the laboratory in ice. The Latin and English names of the 13 different seafood species caught are given in Table 1 . 10 individuals from each species were gutted, filleted and muscle tissue (edible muscle) was minced for analyses.

\subsection{Lipid Analysis and Fatty Acid Methyl Ester analyses (FAME)}

Lipid analysis was performed according to the method of Bligh \& Dyer (1959). Extracted lipid, fatty acids methyl esters were performed according to the method of Ichihara et al. (1996) with minor modifications. $4 \mathrm{~mL}$ of $2 \mathrm{M} \mathrm{KOH}$ and $2 \mathrm{~mL}$ of $\mathrm{n}$-heptane were added to $25 \mathrm{mg}$ of extracted oil sample. It was then vortexed for 2 minutes at room temperature and centrifuged at $4000 \mathrm{rpm}$ for 10 minutes at $4{ }^{\circ} \mathrm{C}$ and the heptane layers were taken up for gas chromatography (GC) analysis.

\subsection{Index of Atherogenicity (IA) and Thrombogenicity (IT)}

The index of atherogenicity and the index of thrombogenicity were calculated with the following equations, as proposed by Ulbricht \& Southgate (1991), taking into account the different effects of different fatty acids on human's health:
The IA and IT linked to the FA composition were calculated according to Ulbricht \& Southgate (1991) (Equations 1, 2). The formulas shown below were used to calculate the index of atherogenicity (IA) and thrombogenicity (IT)

$$
\begin{aligned}
& I A=[(\text { ax C12:0)+(bxC14:0)+(axC16:0)]/ } \\
& {[(\text { d } x(\text { PUFAs } w 6+w 3))+(\text { ex C18:1n9) }+(f x(\text { MUFAs }-C 18: 1 n 9))]} \\
& I T=[(g x(C 14: 0+C 16: 0+C 18: 0))] / \\
& {\left[\begin{array}{l}
(h x C 18: 1 n 9)+(i x(M U F A s-C 18: 1 n 9))+ \\
(m x w 6)+(n x w 3)+(w 3 / w 6)
\end{array}\right.} \\
& \text { a, c, d, e, } \mathrm{f}=1, \mathrm{~b}=4, \mathrm{~g}=1, \mathrm{~h}, \mathrm{i}, \mathrm{m}=0.5 \text { and } \mathrm{n}=3
\end{aligned}
$$

\subsection{Statistical analysis}

A one-way analysis of variance (ANOVA) was run using the SPSS version 22 software (SPSS, Chicago, Illinois, USA). Duncan's multiple range test at $\mathrm{P}$ value of $<0.05$ were used to evaluate the fat content of seafood species.

\section{Results and discussion}

\subsection{Lipid content}

The lipid contents of thirteen different seafood species caught from Mersin Bay in the Northeastern Mediterranean coast are demonstrated in Table 1. Among the seafood species, the highest lipid content was found in shi drum (5.94\%) followed by largehead hairtail (3.12\%) and striped piggy (3.00\%) while the lowest amount of lipid was found in spiny gurnard $(0.90 \%)$ followed by john dory (1.07\%).

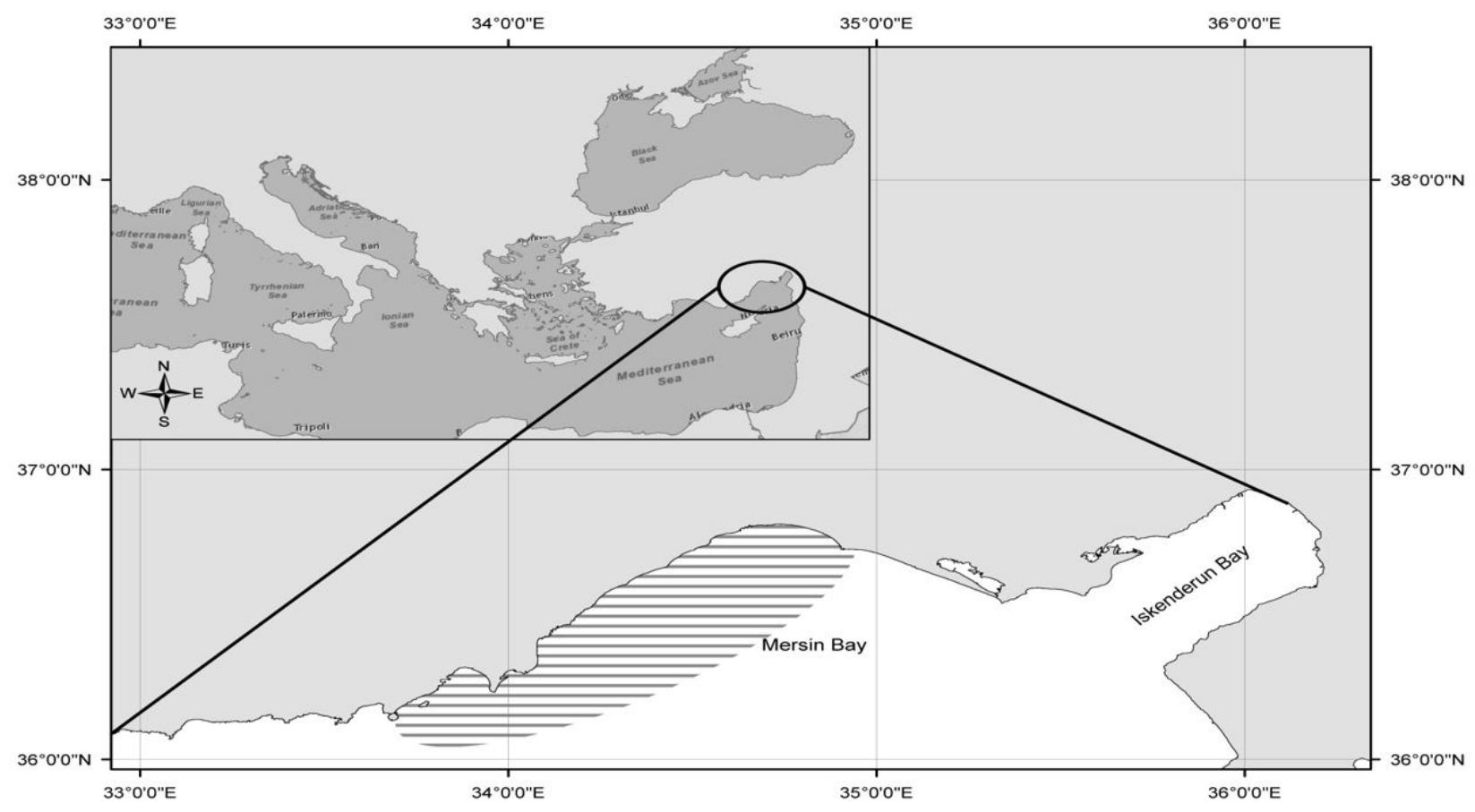

Figure 1. Map of the sampling area. 
Table 1. The lipid content of seafood species caught in the Northeastern Mediterranean coast.

\begin{tabular}{llcc}
\hline \multicolumn{1}{c}{ Fish } & $\mathrm{N}$ & English name & Lipit content \\
\hline Penaeus semisulcatus (De Haan, 1844) & 10 & Green tiger prawn & $1.34 \pm 0.06^{\text {de }}$ \\
Alosa fallax (Lacepède, 1803) & 10 & Twaite shad & $1.37 \pm 0.09^{\mathrm{de}}$ \\
Umbrina cirrosa (Linnaeus, 1758) & 10 & Shi drum & $5.94 \pm 0.34^{\mathrm{a}}$ \\
Zeus faber (Linnaeus, 1758) & 10 & John dory & $1.07 \pm 0.12^{\text {ef }}$ \\
Sparus aurata (Linnaeus, 1758) & 10 & Gilthead seabream & $1.27 \pm 0.19^{\text {def }}$ \\
Fistularia commersonii (Rüppell, 1838) & 10 & Bluespotted cornetfish & $2.29 \pm 0.23^{\mathrm{c}}$ \\
Trichiurus lepturus (Linnaeus, 1758) & 10 & Largehead hairtail & $3.12 \pm 0.19^{\mathrm{b}}$ \\
Lepidotrigla dieuzeidei (Blanc \& Hureau, 1973) & 10 & Spiny gurnard & $0.90 \pm 0.08^{\mathrm{f}}$ \\
Loligo vulgaris (Lamarck, 1798) & 10 & European squid & $1.60 \pm 0.07^{\mathrm{d}}$ \\
Boops boops (Linnaeus, 1758) & 10 & Bogue & $1.12 \pm 0.14^{\mathrm{ef}}$ \\
Scorpaena notata (Rafinesque, 1810) & 10 & Small red scorpionfish & $1.25 \pm 0.16^{\text {def }}$ \\
Serranus cabrilla (Linnaeus, 1758) & 10 & Comber & $1.25 \pm 0.06^{\text {def }}$ \\
Pomadasys stridens (Forsskål, 1775) & 10 & Striped piggy & $3.00 \pm 0.15^{\mathrm{b}}$
\end{tabular}

Values are expressed as $\mathrm{g} / 100 \mathrm{~g}$ wet weight and are means \pm SD. Different letters $(\mathrm{a}-\mathrm{f})$ in the same columns for each species significant differences $(\mathrm{p}<0.05)$

The rate of lipid, one of the basic items of fish meat, varies depending on factors such as nutrition, species, season, geographical region, biological condition, age, gender maturity, reproduction and temperature (Rahnan et al., 1995; Yilmaz et al., 1996; Rasoarahona et al., 2005; Lunn \& Theobald 2006; Ozogul et al., 2007). Ozogul et al. (2009) investigated fat contents and fatty acid profiles of 34 fish species from the Mediterranean Sea. According to the results, the lowest fat concent was reported in leaping mullet $(0.30 \%)$ while the highest fat content was determined in keeled mullet (10.67\%) followed by European barracuda (8.23\%). Li et al. (2011) investigated lipid content and fatty acid profile in edible meats of marine fish, freshwater fish and shrimp from China and reported similar lipid contents in marine fish compared with those in the present study. According to Li et al. (2011), the lipid content ranged from $0.58 \%$ in bluefin leather jacket to $7.83 \%$ in chub mackerel in marine fish, from $1.71 \%$ in swamp eel to $7.43 \%$ in black carp in freshwater fish and from $0.46 \%$ in ridgetail white prawn to $1.86 \%$ in giant freshwater prawn in shrimps. According to the amount of lipid, fish are classified as fatty fish (>10\%), medium-fat fish (5-10\%) and lean fish (lipid content <5\%) (Bennion, 1980). Based on this classification, all seafood in this study except for shi drum were catagorized as lean fish.

\subsection{Fatty acid profiles of seafood}

The fatty acid profile of 13 seafood species are presented in Table 2 . Total saturated fatty acids (SFA), monounsaturated fatty acids (MUFA) and polyunsaturated fatty acids (PUFA) percentages of the total lipid ranged from $27.68 \%$ to $36.59 \%$, from $8.99 \%$ to $35.84 \%$ and from $10.69 \%$ to $39.57 \%$, respectively. Twenty-three fatty acids in muscle lipids of seafood were classified and evaluated. Important fatty acids detected in most of species were myristic acid (C14:0, 0.93-5.59\%), palmitic acid (C16:0, 13.68-23.89\%), palmitoleic acid (C16:1n7, 0.85-6.00\%), heptadecanoic acid (C17:0, 0.67-2.23\%), stearic acid (C18:0, 6.82-10.89\%), vaccenic acid (C18:1n-7, 1.05-4.01\%), oleic acid (C18:1n-9, 4.87-28.73\%), linoleic acid (C18:2n-6, 0.32-2.63\%), arachidonic acid (C20:4n-6, 0.22-0,82\%), cis-5,8,11,14,17-EPA
(C20:5n-3, 1.72-10.73\%) and cis-4,7,10,13,16,19-DHA (C22:6n-3, 4.07-31.44\%). Similarly, many researchers reported that these fatty acids are major fatty acids in marine seafood species (Ozogul et al., 2007, 2009; Li et al., 2011).

Palmitic acid was the major SFA in the current study as many researchers reported that palmitic acid is a dominant saturated fatty acid (Visentainer et al., 2007; Guler et al., 2008; Li et al., 2011). The lowest palmitic acid level was observed in green tiger prawn while the highest palmitic acid was determined in striped piggy. Stearic acid is the second most important saturated fatty acid. Stearic acid among the total saturated fatty acids varies from $20.66 \%$ in largehead hairtail to $35.55 \%$ in small red scorpionfish. Tanakol et al. (1999) investigated the fatty acid compositions of 18 fish species caught in the Black Sea and Marmara Sea. These researchers reported that 18 different species of dominant unsaturated fatty acids are palmitic and stearic acid.

Palmitoleic (C16:1n-7) and oleic acid (C18:1n-9) were found to be dominated in monounsaturated fatty acids. It was determined that $17.16 \%$ in comber and $79.90 \%$ in largehead hairtail of the total mono-saturated fatty acids were these two fatty acids, respectively. Similar to the results of this study, many researchers reported that marine fish contained especially oleic acid (C18: 1n-9) which is dominant fatty acids among MUFAs (Koizumi \& Hiratsuka, 2009; Tanakol et al., 1999; Aydın et al., 2013). Guner et al. (1998) identified fatty acid profile in some species of fish commonly consumed in the Black Sea. These researchers found that palmitoleic $(\mathrm{C} 16: 1 \mathrm{n}-7)$ and oleic acid (C18:1n-9) ranged from $3.76 \%$ in whiting to $11.89 \%$ in red mullet and from $11.60 \%$ in spat to $33.40 \%$ in scad, respectively.

Omega- 3 and omega- 6 fatty acids are called essential fatty acids since they are not synthesized in the human body (Leaf $\&$ Weber, 1988). Thus, these fatty acids must be obtained in adequate amounts from diet. Taking these fatty acids from food are of great importance for metabolic health (Brown, 2000). Omega-3 fatty acids are also abundant in the oil of plants and their products such as hazelnut, walnut, sesame, flaxseed, soybean, canola and olive in addition to seafood products while omega- 6 fatty acids are high in soya, cotton, corn and sunflower oil (Gogus \& Smith, 2010). 
Table 2. The fatty acid profile of seafood species caught in the Northeastern Mediterranean coast.

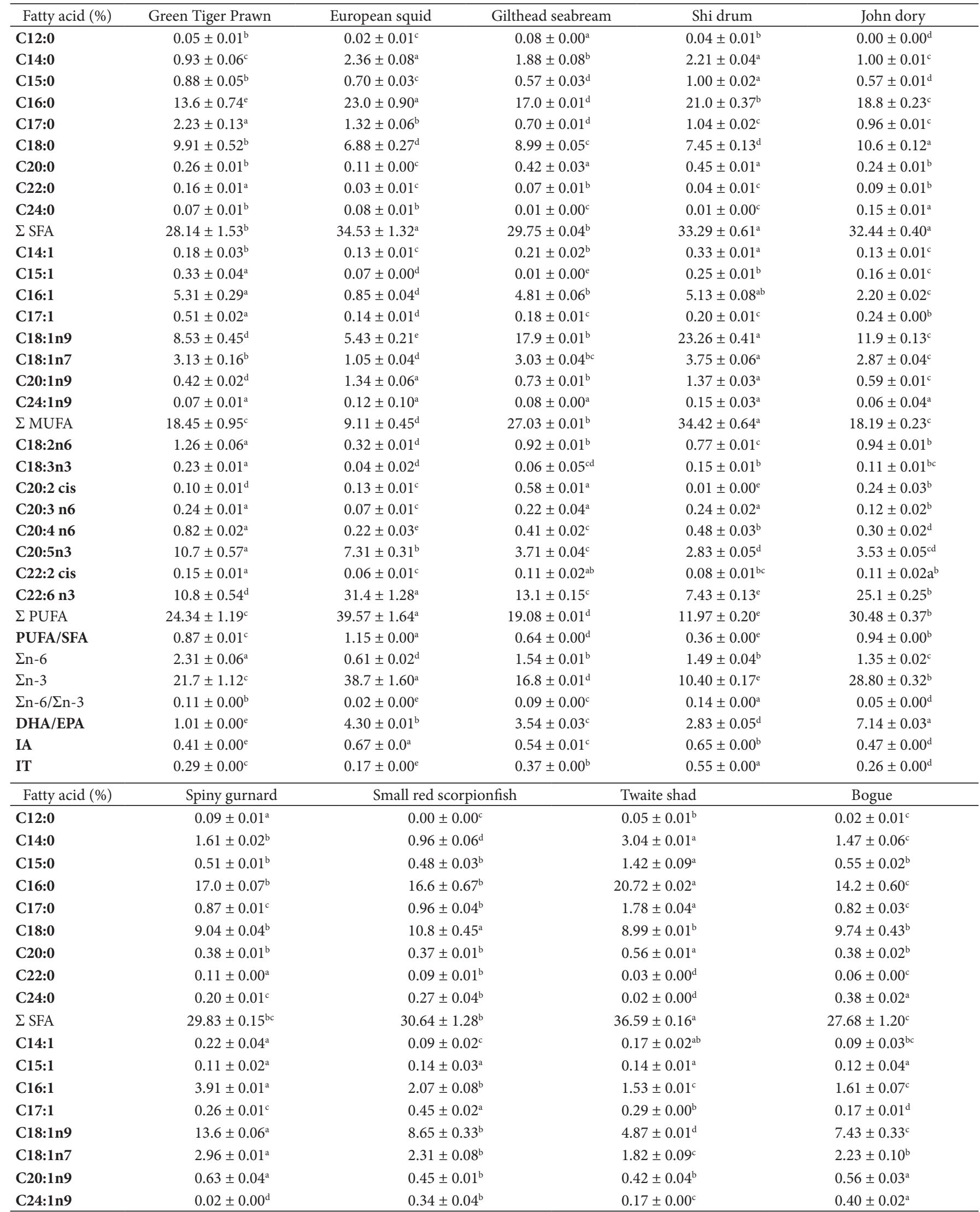

SFAs, saturated fatty acids; MUFAs, monounsaturated fatty acids; PUFAs, polyunsaturated fatty acids; EPA, eicosapentaenoic acid; DHA - docosahexaenoic acid; IA, index of atherogenicity; IT index thrombogenicity. Results are the means \pm S.D. Different letters (a-d) in the same lines for each species significant differences $(\mathrm{p}<0.05)$. 
Table 2. Continued...

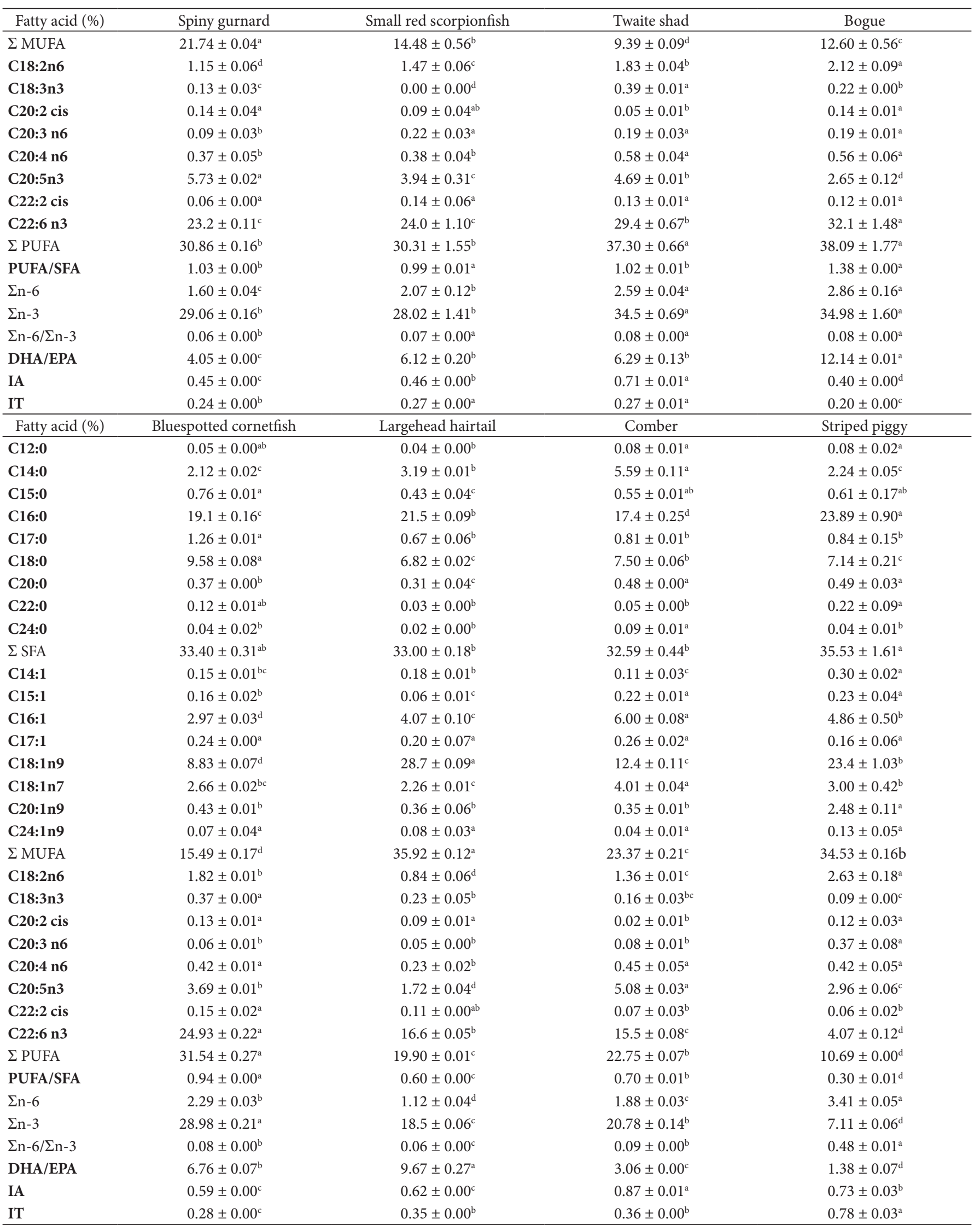

SFAs, saturated fatty acids; MUFAs, monounsaturated fatty acids; PUFAs, polyunsaturated fatty acids; EPA, eicosapentaenoic acid; DHA - docosahexaenoic acid; IA, index of atherogenicity; IT index thrombogenicity. Results are the means \pm S.D. Different letters $(\mathrm{a}-\mathrm{d})$ in the same lines for each species significant differences $(\mathrm{p}<0.05)$. 
Omega-3 fatty acids such as eicosapentaenoic acid (EPA) and decosahexaenoic acid (DHA) are first synthesized by algae such as Chlorella pyrenoidosa, Dunaliella salina, Arthrospira platensis in water (Öztürk, 2014). These fatty acids then accumulate in the fish via the food chain. For this reason, EPA and DHA, which are $\omega-3$ family fatty acids, are essential fatty acids abundantly found in fish (Gordon \& Ratliff 1992). Fish, therefore, are an important dietary source for EPA and DHA, which are essential for human metabolic activities (Leaf \& Weber, 1988).

The highest amount of total PUFA was observed in the European squid (39.57\%), followed by bogue (38.09), twaite shad (37.30\%), bluespotted cornetfish $(31.54 \%)$ and spiny gurnard (30.86\%) while the lowest amount of PUFA was determined in the striped piggy (10.69\%). Similar results were reported in previous studies (Zlatanos \& Laskaridis 2007). The level of EPA in total PUFA, which ranged from $8.64 \%$ of total fatty acids in largehead hairtail to $44.08 \%$ in green tiger prawn, were always lower than those of DHA in total PUFA, which ranged from $38.07 \%$ of total fatty acids in striped piggy to $84.33 \%$ in bogue. It was determined that the seafood species investigated had a high nutritional quality in terms of EPA and DHA values. It is well known that EPA plays an important role in the prevention of cardiovascular diseases, brain disorders and cancer treatment while DHA is necessary for the visual function, growth and brain development (Ward \& Singh, 2005). Gómez Candela et al. (2011) demonstrated that w-3 (DHA and EPA) plays a role in suppressing the development of many cancers including breast, colon, prostate, liver and pancreatic cancers. Whfoods (The World's Healthiest Foods, 2012) reported that two portions per week of non-fried fish may be sufficient to significantly increase the level of omega- 3 fatty acids in the blood.

HMSO UK (Her Majesty's Stationery Office, 1994) suggested that the PUFA / SFA ratio was at least as 0.45 . In the present study, the highest PUFA/SFA ratio was observed in bogue $(1,38)$ followed by European squid (1.15), spiny gurnard (1.04) and twaite shad (1.02) while the lowest value was determined in shi drum (0.36). It was determined that all seafood in this study were above the recommended value except for shi drum. Similar to our study, Ozogul et al. (2009) also reported that the ratio of PUFA/SFA was above the recommended value for 34 fish species from the Mediterranean Sea.

Based on the total amount of w6 and w3 PUFA, it was determined that the total w3 amount was more than the total w6 amount in all species in this study. It has been suggested that the ratio of $\mathrm{w} 6 / \mathrm{w} 3$ was useful indicators to compare the relative nutritional values of fish oils (Pigott \& Tucker, 1990). It was reported that the ratio of omega-6/omega- 3 should be kept as low as 1:1 or 2:1 (Gómez Candela et al., 2011; Granados et al., 2006). The UK Department of Health has proposed a rate of w6/w3 of maximum 4 ( Her Majesty's Stationery Office, 1994). A low omega-6/omega-3 ratio was associated with a reduced risk of breast cancer in women and also positive affect on asthmatic patients (Simopoulos, 2004). Reduction in the ratio of w6/w3 fatty acids in the human diet was essential to help prevent coronary heart disease and to reduce the risk of cancer (Kinsella et al., 1990). The ratio of w6 PUFAs/w3 PUFAs in total lipids of 13 different seafood species caught in the Northeastern
Mediterranean coast ranged from 0.02 in European squid to 0.48 in striped piggy. Ozogul et al. (2009) found similar results in 34 fish species from the Mediterranean Sea. Similarly, Ayas et al. (2013) reported that the $\mathrm{w} 6 / \mathrm{w} 3$ ratio of shrimp varied between 0.2 and 0.7 . In this study, w6/w3 ratios were in the range of recommended levels by researcher (Gómez Candela et al., 2011; Granados et al., 2006). In France and Norway daily EPA and DHA intake levels were recommended to be $500 \mathrm{mg} /$ day and 1-2 g/day, respectively (Gómez Candela et al., 2011). The World Health Organization (WHO) recommends this consumption as 0.3-0.5 g/day. Moreover, American Heart Association (AHA) advises adults to consume fish at least twice a week.

Lipid quality indicators that depend on the relative contents of particular groups of FAs are the IA and IT, which indicate the global dietetic quality of lipids and their potential effect on the development of coronary disease (Ulbricht \& Southgate 1991). In current study, IA and IT values ranged from 0.40 to 0.87 and from 0.17 to 0.79 , respectively (Table 2 ). The highest IA and IT values were obtained from comber and striped piggy whereas the lowest values were determined in bogue and European squid. Similar to this study, Valfré et al. (2003) reported that the IA and IT values of the different seafoods varied from species to species. Turan et al. (2011) reported that the IT and IA values for brown shrimp were 0.31 and 1.34, respectively. Ayas et al. (2013) found that IA values varied between 0.27 for kuruma prawnin spring and 0.48 for caramote prawn and speckled shrimpin while TI values varied from 0.21 for kuruma prawn and to 0.30 for green tiger prawn, speckled shrimp and deepwater pink shrimp.

\section{Conclusion}

The w3 fatty acids can be used as pharmaceuticals since the consumption of marine oils provides numerous health benefits. It is well documented that the lipid content and FA profiles of fish vary between/within species even in dark and white muscle, which are affected by many factors i.e. diet, temperature, salinity, season, size, age, spawning period. The current study showed that when the levels of EPA, DHA and w6/w3 are considered, all species were rich in PUFA (especially EPA and DHA) and can be used as good marine oil sources.

\section{Acknowledgements}

This research was carried out at the Faculty of Fisheries, Cukurova University. The author is grateful to Professor Dr. Yesim Ozogul and other colleagues for their valuable time during the research.

\section{References}

Ackman, R. G. (1989). Nutritional composition of fats in seafoods. Progress in Food \& Nutrition Science, 13(3-4), 161-289. PMid:2699043.

Asztalos, I. B., Gleason, J. A., Sever, S., Gedik, R., Asztalos, B. F., Horvath, K. V., Dansinger, M. L., Lamon-Fava, S., \& Schaefer, E. J. (2016). Effects of eicosapentaenoic acid and docosahexaenoic acid on cardiovascular disease risk factors: a randomized clinical trial. Metabolism: Clinical and Experimental, 65(11), 1636-1645. http:// dx.doi.org/10.1016/j.metabol.2016.07.010. PMid:27733252. 
Ayas, D., Ozogul, Y., \& Yazgan, H. (2013). The effects of season on fat and fatty acids contents of shrimp and prawn species. European Journal of Lipid Science and Technology, 115(3), 356-362. http:// dx.doi.org/10.1002/ejlt.201200081.

Aydın, M., Tufan, B., Sevgili, H., \& Köse, S. (2013). Seasonal changes in proximate composition and fatty acid profile of pufferfish (Lagocephalus sceleratus Gmelin, 1789) from the Mediterranean Sea of Turkey. Journal of Aquatic Food Product Technology, 22(2), 178-191. http://dx.doi.org/10.1080/10498850.2011.638151.

Bennion, M. (1980). Introductory foods (7th ed.). New York: Macmillan.

Bligh, E. C., \& Dyer, W. J. (1959). A rapid method of total lipid extraction and purification. Canadian Journal of Biochemistry and Physiology, 37(8), 913-917. http://dx.doi.org/10.1139/o59-099. PMid:13671378.

Brown, A. (2000). Understanding food. Fish and shellfish (299 p.). Wadsworth: Thomson Learning.

Cardona, L., Martínez-Iñigo, L., Mateo, R., \& González-Solís, J. (2015). The role of sardine as prey for pelagic predators in the western Mediterranean Sea assessed using stable isotopes and fatty acids. Marine Ecology Progress Series, 531, 1-14. http://dx.doi.org/10.3354/ meps11353.

Fung, T., Rexrode, K. M., Mantzoros, C. S., Manson, J. E., Willett, W. C., \& Hu, F. B. (2009). Mediterranean diet and incidence of and mortality from coronary heart disease and stroke in women. Circulation, 119(8), 1093-1100. http://dx.doi.org/10.1161/ CIRCULATIONAHA.108.816736. PMid:19221219.

Gispert-Llaurado, M., Perez-Garcia, M., Escribano, J., Closa-Monasterolo, R., Luque, V., Grote, V., Weber, M., Torres-Espínola, F. J., CzechKowalska, J., Verduci, E., Martin, F., Piqueras, M. J., Koletzko, B., Decsi, T., Campoy, C., \& Emmett, P. M. (2016). Fish consumption in mid-childhood and its relationship to neuropsychological outcomes measured in 7-9 year old children using a nutrımenthe neuropsychological battery. Clinical Nutrition (Edinburgh, Lothian), 35(6), 1301-1307. http://dx.doi.org/10.1016/j.clnu.2016.02.008. PMid:26968967.

Gogus, U., \& Smith, C. (2010). n-3 omega fatty acids: a review of current knowledge. International Journal of Food Science \& Technology, 45(3), 417-436. http://dx.doi.org/10.1111/j.1365-2621.2009.02151.x.

Gómez Candela, C., Bermejo López, L. M., \& Loria Kohen, V. (2011). Importance of a balanced omega 6/omega 3 ratio for the maintenance of health. Nutritional recommendations. Nutrición Hospitalaria, 26(2), 323-329. PMid:21666970.

Gordon, D. T., \& Ratliff, V. (1992). The implications of omega-3fatty acits in human healty. In G. L. Flick (Ed.), Advances in seafood biochemistry composition and quality (406 p.). Boca Raton: CRC Press.

Graciano, M. F., Leonelli, M., Curi, R., \& Carpinelli, A. R. (2016). Omega-3 fatty acids control productions of superoxide and nitrogen oxide and insulin content in INS-1E cells. Journal of Physiology and Biochemistry, 72(4), 699-710. http://dx.doi.org/10.1007/s13105-0160509-1. PMid:27474043.

Granados, S., Quiles, J. L., Gil, A., \& Ramírez-Tortosa, M. C. (2006). Lípidos de la dieta y cáncer. Nutrición Hospitalaria, 21, 44-54.

Guler, G. O., Kiztanir, B., Aktumsek, A., Citil, O. B., \& Ozparlak, H. (2008). Determination of the seasonal changes on total fatty acid composition and $\omega 3 / \omega 6$ ratios of carp (Cyprinus carpio L.) muscle lipids in Beysehir Lake (Turkey). Food Chemistry, 108(2), 689-694. http://dx.doi.org/10.1016/j.foodchem.2007.10.080. PMid:26059149.

Guner, S., Dincer, B., Alemdag, N., Colak, A., \& Tüfekci, M. (1998). Proximate composition and selected mineral content of commercially important fish species from the Black Sea. Journal of the Science of
Food and Agriculture, 78(3), 337-342. http://dx.doi.org/10.1002/ (SICI)1097-0010(199811)78:3<337::AID-JSFA122>3.0.CO;2-A.

He, Y., Li, J., Kodali, S., Chen, B., \& Guo, Z. (2017). Rationale behind the near-ideal catalysis of Candida antarctica lipase A (CAL-A) for highly concentrating $\omega-3$ polyunsaturated fatty acids into monoacylglycerols. Food Chemistry, 219, 230-239. http://dx.doi. org/10.1016/j.foodchem.2016.09.149. PMid:27765222.

Her Majesty's Stationery Office - HMSO. (1994). Nutritional aspects of cardiovascular disease. Report of the Cardiovascular Review Group Committee on Medical Aspects of Food Policy. Rep Health Soc Subj (Lond), 46:1-186.

Ichıhara, K., Shıbahara, A., Yamamoto, K., \& Nakayama, T. (1996). An improved method for rapid analysis of the fatty acids of glycerolipids. Lipids, 31(5), 535-539. http://dx.doi.org/10.1007/BF02522648. PMid:8727647.

Itsiopoulos, C., Hodge, A., \& Kaimakamis, M. (2009). Can the Mediterranean diet prevent prostate cancer? Molecular Nutrition \& Food Research, 53(2), 227-239. http://dx.doi.org/10.1002/ mnfr.200800207. PMid:19051189.

Kaya, Y., Duyar, H. A., \& Erdem, M. E. (2004). Balık yağ asitlerinin insan sağllğı için önemi. Ege Üniv. Su Ürünleri Dergisi, 21(3/4), 365-370.

Kinsella, J. E., Lokesh, B., \& Stone, R. A. (1990). Dietary n-3 polyunsaturated fatty acids and amelioration of cardiovascular disease: possible mechanisms. The American Journal of Clinical Nutrition, 52(1), 1-28. http://dx.doi.org/10.1093/ajcn/52.1.1. PMid:2193500.

Koizumi, K., \& Hiratsuka, S. (2009). Fatty acid compositions in muscles of wild and cultured ocellate puffer Takifugu rubripes. Fisheries Science, 75(5), 1323-1328. http://dx.doi.org/10.1007/s12562-009-0151-8.

Kris-Etherton, P. M., Harris, W. S., \& Appel, L. J. (2003). Fish consumption, fish oil, omega_3 fatty acids and cardiovascular disease. Circulation, 106(21), 2747-2757. http://dx.doi.org/10.1161/01. CIR.0000038493.65177.94. PMid:12438303.

Leaf, A., \& Weber, P. C. (1988). Cardiovascular effects of n-3 fatty acids. The New England Journal of Medicine, 318(9), 549-557. http://dx.doi. org/10.1056/NEJM198803033180905. PMid:3277056.

Li, G., Sinclair, A. J., \& Li, D. (2011). Comparison of lipid content and fatty acid composition in the edible meat of wild and cultured freshwater and marine fish and shrimps from China. Journal of Agricultural and Food Chemistry, 59(5), 1871-1881. http://dx.doi. org/10.1021/jf104154q. PMid:21291233.

Lordan, S., Ross, R. P., \& Stanton, C. (2011). Marine bioactives as functional food ingredients: potential to reduce the incidence of chronic diseases. Marine Drugs, 9(6), 1056-1100. http://dx.doi. org/10.3390/md9061056. PMid:21747748.

Lunn, J., \& Theobald, H. E. (2006). The health effects of dietary unsaturated fatty acids. Nutrition Bulletin, 31(3), 178-224. http:// dx.doi.org/10.1111/j.1467-3010.2006.00571.x.

Mnari, A., Bouhlel, I., Chraief, I., Hammami, M., Romdhane, M. S., El Cafsi, M., \& Chaouch, A. (2007). Fatty acids in muscles and liver of Tunisian wild and farmed gilthead sea bream, Sparus aurata. Food Chemistry, 100(4), 1393-1397. http://dx.doi.org/10.1016/j. foodchem.2005.11.030.

Mol, S. (2008). Balık Yağı Tüketimi ve İnsan Sağlığı Üzerine Etkileri. Journal of Fisheries Sciences, 2(4), 601-607.

Ozogul, Y., Ozogul, F. H., Çiçek, E., Polat, A., \& Kuley, E. (2009). Fat content and fatty acid compositions of 34 marine water fish species from the Mediterranean Sea. International Journal of Food Sciences and Nutrition, 60(6), 464-475. http://dx.doi.org/10.1080/09637480701838175. PMid:18972241. 
Ozogul, Y., Ozogul, F., \& Alagoz, S. (2007). Fatty acid profiles and fat contents of commercially important seawater and freshwater fish species of Turkey: A comparative study. Food Chemistry, 103(1), 217-223. http://dx.doi.org/10.1016/j.foodchem.2006.08.009.

Öztürk, M. O. (2014). Esansiyel yağ asitlerinin insan metabolizması ve beslenmesi üzerine etkileri. Kocatepe Veterinary Journal, 7(2), 37-40.

Ozyurt, G., \& Polat, A. (2006). Amino acid and fatty acid composition of wild sea bass (Dicentrarchus labrax): a seasonal differentiation. European Food Research and Technology, 222(3-4), 316-320. http:// dx.doi.org/10.1007/s00217-005-0040-z.

Palmquist, D. L. (2009). Omega-3 fatty acids in metabolism, health, and nutrition and for modified animal product foods. The Professional Animal Scientist, 25(3), 207-249. http://dx.doi.org/10.15232/S10807446(15)30713-0.

Pethybridge, H., Bodin, N., Arsenault-Pernet, E. J., Bourdeix, J. H., Brisset, B., Bigo, J. L., Roos, D., \& Peter, M. (2014). Temporal and inter-specific variations in forage fish feeding conditions in the NW Mediterranean: lipid content and fatty acid compositional changes. Marine Ecology Progress Series, 512, 39-54. http://dx.doi. org/10.3354/meps10864.

Pigott, G. M., \& Tucker, B. W. (1990). Seafood effects of technology on nutrition. New York: Marcel Dekker, Inc.

Pinel, A., Morio-Liondore, B., \& Capel, F. (2014). n-3 Polyunsaturated fatty acids modulate metabolism of insulinsensitive tissues: implication for the prevention of type 2 diabetes. Journal of Physiology and Biochemistry, 70(2), 647-658. http://dx.doi.org/10.1007/s13105013-0303-2. PMid:24371037.

Raatz, S., \& Bibus, D. (2016). Fish and fish oil in health and disease prevention. USA: Academic Press. https://doi.org/10.1016/C20140-02727-X.

Rahnan, S. A., Huah, T. S., Nassan, O., \& Daud, N. M. (1995). Fatty acid composition of some malaysian fresh water fish. Food Chemistry, 54(1), 45-49. http://dx.doi.org/10.1016/0308-8146(95)92660-C.

Rasmussen, R. S., \& Morrissey, M. T. (2007). Marine biotechnology for production of food ingredients. Advances in Food and Nutrition Research, 52, 237-292. http://dx.doi.org/10.1016/S1043-4526(06)520054. PMid:17425947.

Rasoarahona, J. R. E., Barnathan, G., Bianchini, J. P., \& Gaydou, E. M. (2005). Influence of season on the lipid content and fatty acid profiles of three tilapia species (Oreochromis niloticus, O. macrochir and Tilapia rendalli) from Madagascar. Food Chemistry, 91(4), 683694. http://dx.doi.org/10.1016/j.foodchem.2004.07.001.

Rendeiro, C., Sheriff, A., Bhattacharya, T. K., Gogola, J. V., Baxter, J. H., Chen, H., Helferich, W. G., Roy, E. J., \& Rhodes, J. S. (2016). Long-lasting impairments in adult neurogenesis, spatial learning and memory from a standard chemotherapy regimen used to treat breast cancer. Behavioural Brain Research, 315, 10-22. http://dx.doi. org/10.1016/j.bbr.2016.07.043. PMid:27478140.

Saito, H., Yamashiro, R., Alasalvar, C., \& Konno, T. (1999). Influence of diet on fatty acids of three subtropical fish, subfamily caesioninae (Caesio diagramma and C. tile) and family siganidae (Siganus canaliculatus). Lipids, 34(10), 10731082. http://dx.doi.org/10.1007/ s11745-999-0459-4. PMid:10580335.

Shepherd, C. J., \& Jackson, A. J. (2013). Global fishmeal and fish-oil supply: inputs, outputs and marketsa. Journal of Fish Biology, 83(4), 1046-1066. PMid:24090562.
Simopoulos, A. P. (2004). Omega-6/omega-3 essential fatty acid ratio and chronic diseases. Food Reviews International, 20(1), 77-90. http://dx.doi.org/10.1081/FRI-120028831.

Stoll, B. A. (2002). N-3 fatty acids and lipid peroxidation in breast cancer inhibition. British Journal of Nutrition, 87(3), 193-198. http://dx.doi. org/10.1079/BJN2001512. PMid:12064327.

Suleria, H. A. R., Gobe, G., Masci, P., \& Osborne, S. A. (2016). Marine bioactive compounds and health promoting perspectives; innovation pathways for drug discovery. Trends in Food Science \& Technology, 50, 44-55. http://dx.doi.org/10.1016/j.tifs.2016.01.019.

Tanakol, R., Yazici, Z., Şener, E., \& Sencer, E. (1999). Fatty acid composition of 19 species of fish from the Black Sea and the Marmara Sea. Lipids, 34(3), 291-297. http://dx.doi.org/10.1007/s11745-9990366-8. PMid:10230724.

The World's Healthiest Foods - Whfoods. (2012). Omega-3 fatty acids. Retrieved from 5 december 2017, http://whfoods.org/genpage. php? tname $=$ nutrient $\& d b i d=84$

Tort, O., Sánchez-Palomino, S., Escribà, T., Calvo, C., González, T., Gatell, J. M., Sala-Vila, A., \& Arnedo, M. (2016). $\omega$-3 supplementation in HIV-1-infected individuals with unsuppressed viral load: cause for caution? AIDS (London, England), 30(17), 2733-2735. http://dx.doi. org/10.1097/QAD.0000000000001274. PMid:27782969.

Turan, H., Kaya, Y., \& Erdem, M. E. (2011). Proximate composition, cholesterol, and fatty acid content of brown shrimp (Crangon crangon L. 1758) from Sinop Region, Black Sea. Journal of Aquatic Food Product Technology, 20(1), 100-107.

Ulbricht, T. L. V., \& Southgate, D. A. T. (1991). Coronary heart disease: seven dietary factors. Lancet, 338(8773), 985-992. http://dx.doi. org/10.1016/0140-6736(91)91846-M. PMid:1681350.

Valfré, F., Caprino, F., \& Turchini, G. M. (2003). The health benefit of seafood. Veterinary research communications. Veterinary Research Communications, 27(Suppl 1), 507-512.

Vieira, A. D. S., \& Silveira, G. R. M. D. (2017). Effectiveness of n-3 fatty acids in the treatment of hypertriglyceridemia in HIV/AIDS patients: a meta-analysis. Ciencia \& Saude Coletiva, 22(8), 2659-2669. http:// dx.doi.org/10.1590/1413-81232017228.21752015. PMid:28793080.

Visentainer, J. V., Noffs, M. D., Carvalho, P. O., Almeida, V. V., Oliveira, C. C., \& Souza, N. E. (2007). Lipid content and fatty acid composition of 15 marine fish species from the southeast coast of Brazil. Journal of the American Oil Chemistiry Society, 84(6), 543-547. http://dx.doi. org/10.1007/s11746-007-1070-4.

Ward, Q. W., \& Singh, A. (2005). Omega-3/6 fatty acids: alternative sources of production. Process Biochemistry, 40(12), 3631. http:// dx.doi.org/10.1016/j.procbio.2005.02.020.

Yılmaz, Ö., Konar, V., \& Çelik, S. (1996). Elazığ keban baraj gölünde yaşayan Capoeta capoeta umbla ve Capoeta trutta'nın toplam lipid ve yağ asiti bileşimi. Gıda Dergisi, 21(6), 477-483.

Zlatanos, S., \& Laskaridis, K. (2007). Seasonal variation in the fatty acid composition of three Mediterranean fish-sardine (Sardina pilchardus), anchovy (Engraulis encrasicholus) and picarel (Spicara smaris). Food Chemistry, 103(3), 725-728. http://dx.doi.org/10.1016/j. foodchem.2006.09.013. 